\title{
Our Vanishing Government of Laws
}

\author{
William B. Munro*
}

L AWYERS hardly need to be told that some long-honored American traditions are rapidly passing into eclipse. One of them is the belief in "a government of laws, not of inen". That belief was cherished by our people through four generations, although sometimes with only a vague notion of what it meant. But in a general way it was taken to mean that the American system of government, being a government of laws, was in soine mysterious fashion safeguarded against the uncertainties which are associated with a government of men. A Gallup poll would probably disclose that ninety per cent of our people still think that way. They continue to believe that the laws which govern them are being nade by their elected representatives and that the function of the administration is merely to administer these laws. But no careful observer of governmental trends has any such idea. Surveying the political scene of today he feels as though he were sitting on the rear platform of a train gazing at a rapidly receding landscape.

"One of the ablest administrators that it was iny good fortune to know," says a recent writer, "I believe, never read, at least more than casually, the statutes that he translated into reality. He assumed that they gave him power to deal with the broad problems of industry and, upon that understanding, he sought his own solutions." 1 These are the words of one whose distinction in both legal and administrative circles gives him the right to speak with some authority. But when administrators disdain even to read the statutes from which they derive their powers and pontifically assume that they have a right to deal with broad problems of industry in their own unfettered way-are we not then well on our way towards a government of men?

It is true, of course, that in a literal sense we have never had a government of laws, that is, of laws alone. Laws are inanimate things and have no inotion of their own. They gain momentum only when they are administered and interpreted by men. In all ages a governunent of laws has been a government by the men who make the laws,

*Edward S. Harkness Professor of History and Government, California Institute of Technology.

1 Landis, The Adurnistrative Process (1938) 75. 
and by other men who put the laws into operation. So the difference between a government of laws and a government of men is partly one of degree and partly one of governmental structure. It depends upon the extent to which administrative discretion replaces the customary process of legislation. It also depends upon whether the making and enforcement of regulatory orders are combined in the same hands or kept separate. A government of men is one in which laws and lawmakers are relegated to a secondary place in the body politic, while administrators and their administrative regulations increasingly control the activities of the people.

One does not need to argue the point that we have gone a long way in this direction during the past decade. The distance is such that it is no longer sufficient for a lawyer to know "the law" in its customary sense. He must extend the scope of his knowledge far beyond statutory enactments and judicial decisions. In many cases his practice now deals mainly, not incidentally, with the interpretation of rulings made by taxing authorities, rate-fixing bodies, by labor boards both state and national, as well as by the numerous commissions, bureaus, offices and other administrative agencies which supervise and regulate all manner of things from banking and insurance to horse racing and hair dressing. There is today hardly a trade or vocation which does not, in some of its operations, come under the hand of governmental regulation-national, state or local. No longer are the lawmaker and the judge our primary symbols of public authority. Boards and bureaus have been edging them out. Sparrows are flocking into the eagle's nest.

Nor is it any longer enough for the citizen to obey the laws and ordinances that stand on the statute books. He must conform his daily walk and conversation to the unending shower of orders, rulings and directives which fly from these administrative agencies like sparks from a blacksmith's anvil. To say that these bodies are merely exercising a delegated legislative function and doing only what the statutes authorize them to do, is to gloss the realities with a legal fiction. The statutes give them wide latitude and when this is not enough they stretch it further. As a matter of political realism there are few things more elastic than the initial jurisdiction of an ambitious administrative agency, and fewer things more rigid than its tenacity in holding whatever it lays hands upon. Congress and the state legislatures have been giving these regulatory bodies an unprecedented amount of power and discretion, far more than would 
have been tolerated by public opinion a generation ago; yet even this has not always been enough to satisfy the officials concerned. They have asked for more, or have taken it without the asking.

But one should not make the error of thinking that this devolution of discretionary powers into the hands of the administration is a new phenomenon in American government. To some extent the practice has been followed from the beginning. Congress, in the very first year of its existence, gave the President power to make administrative regulations covering various inatters. This is not surprising, for a political system cannot function efficiently without having the rigidity of the laws softened by some degree of executive discretion. But throughout the greater portion of American history it was the habit of legislatures to elaborate the provisions of a statute in such detail that not much was left to the judgment of any executive or administrative authority. During more recent years, however, legislatures have found themselves wholly unable to do this. The task has been too great. Not by choice but by necessity they have been forced to content themselves with enacting legislation in the broad-leaving the detailed application to be worked out by boards, commissions, or other administrative tribunals established for this purpose. Compare, for example, the Interstate Commerce Act of $1887^{2}$ with the Securities Exchange Acts of $1933-1934^{3}$ and you will see what a change in legislative technique has taken place in the intervening half century.

As a result of this extensive transfer of responsibility from the legislative to the executive branch of the government there has been built up a great body of "administrative law" which already far exceeds in volume the statutory law of the land. This term, borrowed from Europe, is not an altogether happy one, for by parading itself as law it has gained in the American public unind a connotation that it does not deserve. Perhaps the most far-reaching change that has been wrought in the American political system during recent years is the abdication by legislatures of a large part of their traditional function and its assumption by those who are not the elected representatives of the people. To admit that this transfer has been unavoidable does not dimimish its significance.

Something of the same sort, it may be noted, has always taken place in times of social and economic revolution. When an old order

224 Stat. 379.

849 Stat. (1933) 74, 48 Stat. (1934) 881, 15 U.S.C. (1940) cs. 2A, 2B. 
is crumbling and giving place to a new one the existing categories of the law are found inadequate to the new popular demands. On the other hand these demands are not, at the moment, sufficiently well defined to be given a means of facilitation in the general body of the law. It takes time to achieve any approach to a consensus on just what measure of social reconstruction the people want, when they seem to want it. Some expedient must, therefore, be found for giving their new aspirations a lift along the way. And the simplest method of doing this is to set up admimistrative tribunals, endowed with such praetorian powers as will enable them to keep governmental action in contact with what the people are calling upon their government to do. Revolutions, because of the speed at which they move, require a departure from the orderly constitutional process. They have done so in all ages.

What has been taking place in the Umited States, therefore, is not the appearance of a new governmental phenomenon but the reappearance of a very old one. It is a phenomenon that has come to the fore in every era of rapid transition, and perhaps happily so, for the perpetuation of free government would be endangered if some such safety-valve were not at hand for use in emergencies. When a democracy comes face to face with a great upsurge of popular clamor for increased governmental control over the economic activities of the people, or for some general redesigning of the social pattern, this demand cannot be satisfied by simply referring it to the slow and cumbersome procedure by which the laws are frained, enacted, interpreted, and administered in normal times. Quick action must be taken in such emergencies by setting up administrative agencies with authority to act quickly, vigorously, and if need be with finality. Then, when the emergency is past, these bodies can be abolished or retained as conditions dictate. It is quite true, as everyone knows, that an emergency board or bureau is not easily abolished when the need which called it into existence is past; but it can be done, and has been done, as the experience of the Umited States after the first World War discloses.

So the question is not whether the great expansion of administrative regulation in the Umited States, even during the years preceding the present war, has been wise or unwise. There was no alternative. The social and economic revolution which began in the United States ten years or more ago, and which is not yet at an end-this stupendous upheaval could hardly have been kept under control by 
utilizing only the traditional procedures. One may hasten to add, however, that the distribution of emergency powers might have been made with better judgment, with less overlapping of administrative jurisdiction, with more adequate checks on the cost of it, and with the selection of more capable personnel for these new posts of high responsibility. But if the job was none-too-well-handled, one should remember that it has been a gigantic one-perhaps the biggest that the nation has ever tackled in all its history-and it is not yet finished. How much farther we will go in the multiplication of administrative functionaries by a process of geometrical progression is something that no one can now forecast.

But there is already momentun enough to carry it a long way, and its popularity with those who are the chief beneficiaries of it can hardly be questioned. In the minds of administrators this kind of law, made by two or three bureaucrats, or even by a single one, has great advantages over any other kind. It has more resiliency than attaches to ordinary law. Its provisions can be changed overnight, sometimes without notice to anybody. The long and cumbrous procedure which the making of ordinary law requires is eliminated. A few commissioners just go into a huddle and out comes a new administrative order or directive which may affect the welfare, comfort or convenience of millions. There is no need for lengthy public hearings as in the consideration of legislative measures, no reference to committees for study, no three readings, and no concurrence on the part of two chambers before some bright idea acquires the force of law. In the making of administrative law nearly all safeguards against precipitous and arbitrary action which we have built up in legislatures are cast aside.

Ordinary laws, moreover, are interpreted and enforced by the regular courts. These courts are required to follow procedures which have been worked out, over long periods of time, with great solicitude for the idea of giving everyone his day in court. But administrative tribunals make their own rules of procedure and can usually change them at will. They are under no obligation to place the private citizen on a plane of equality with his government. A regulatory board or bureau can, and often does, make determinations and issue orders based upon the reports and recommendations of its own examiners who have been sent to inquire into the facts and who use their own technique in ascertaining them.

There is a saying in governmental circles that "a regulatory law 
should be administered by its friends". That is another way of suggesting that when something needs to be regulated, the work of regulation should be entrusted to men who will do it with crusading fervor. Of course there is something to be said for this point of view; at any rate it is apparent that the personnel of administrative agencies is frequently selected on some such basis. Surely no one will seriously contend that in choosing the members of regulatory boards, whether in national or state government, the appointing authorities have been motivated by the sole desire to discover men who would administer the law with an equal eye and an even hand. Yet the performance of a quasi-judicial task would seem to require at least a quasi-judicial temperament. The problem is to develop an atmosphere in which controversie receive a full and fair hearing, so that the determinations will not be ex parte or arbitrary. This can hardly be accomplished by devolving the work upon men of Messianic aspirations.

Furthermore, since the matters which come before administrative agencies are often of a complex and technical character it would seein logical that training and experience should be important factors in the selection of personnel. Those who are set to supervise banks, public utilities, transportation, radio broadcasting or labor relations should presumably be men who either have special conpetence for the work or are able to acquire it. In some cases they meet that specification, but in others (perhaps the majority) the appointments are dictated by the exigencies of politics. This, I believe, is true of appointments to regulatory bodies in most of the states. Men are appointed to these administrative agencies as a matter of patronage, as a reward for loyal party service, no matter which political party is in power. It is true, no doubt, that when such appointees are left in office for successive terms they may develop considerable expertness; but the terms are usually short and the changes frequent, so that this opportunity is the exception rather than the rule. Much of the skepticism with which thoughtful people regard the multiplication of administrative agencies is related to personnel rather than to policy itself. Too many lame duck legislators have been involved.

Now it might be thought that such a situation would call for apology rather than for defense. But the practice of treating these administrative posts as patronage, when the need arises, has not lacked defenders. One of them puts it this way: "Inasmuch as good will is essential in order to assure uninterrupted means for the effective pursuit of policies, personal antagonisins arising out of a disregard of 
patronage problems cannot be ignored. On occasion it may even be necessary to cement alliances by a wise use of the power of appointment." " In other words the end, to wit, the effective pursuit of an administration's policy, is deemed to justify the means, which is our old friend the spoils system. But let it only be agreed that the use of the appointing power to cement alliances is a wise use and there will be plenty of occasion for using it.

Likewise a good deal of criticism has been related to the procedure under which administrative agencies frequently operate. For this procedure sometimes sets at defiance certain canons of fair adjudication which have become firmly imbedded in the public mind. One of these is the principle that no one is presumed to be a violator of the law until such violation is proved beyond reasonable doubt. Another gives everyone the right to his day in court, that is the right to a full presentation of his side of the case. A third postulates the equal status of all parties at the bar of justice. And there is the axiom that no one should serve in the dual capacity of prosecutor and judge.

The presumption of innocence on the part of anyone who is hailed before the regular courts has long been a cornerstone of the judicialized process. It is a workable presumption because the judge has no responsibility towards the issue which is before him except to decide it. He has had no part in bringing the complaint or preparing the case. He hears the testimony under rules which he has had no part in making, and renders his judgment after everything that is admissible under these rules has been heard. His decisions, moreover, and all the considerations leading to it, are matters of public record and in most cases are subject to review by a higher court.

All too frequently, these sound principles of fair adjudication seem to be disregarded by administrative agencies acting in a quasijudicial capacity. Where a complaint is initiated by a regulatory board, and when the case is worked up by one or more of its own examiners or other subordinates, there is an obvious difficulty in believing that the respondent comes before the board with a presumption in his favor. Dean Roscoe Pound has expressed concern over the tendency of administrative tribunals to decide matters and issue rulings without formal hearings, or after hearing only one of the parties, sometimes in the absence of the other whose interests are adverse. ${ }^{5}$

4 LaNDis, op. cit. supra note 1 , at 62 .

6 At the Indianapolis meeting of the American Bar Association, (1941) 27 A. B. A. J. 664. 
Those who are hailed before administrative agencies, at any rate, often feel that they have not been fully apprised of the issues which they were expected to meet, or given a fair opportunity to prepare the supporting data. Determinations by admimistrative tribunals have sometimes been virtually based upon the reports of examiners, the contents of which are not always publicly divulged.

Complaint is also made, and apparently with reason, that the administrative procedure has been taking undue liberties with the principle of "judicial notice". Lawyers are familiar with the rule that there are various matters of common notoriety which do not have to be proved in the regular courts by the submission of evidence. The fact that the Fourth of July is a national holiday, for example, or that the nation is now at war-judicial notice will be taken of such things without the necessity of proving them. This is both common law and common sense so long as the courts restrict their taking of judicial notice to matters on which there is and can be no dispute, which is what they have done.

But the administrative tribunals, some of them, are giving this primciple a considerable extension. And here is the way one writer defends their action:

“. . . matters which may properly be subjects of official notice are those of which the agency has acquired knowledge in the course of its ordinary business. These matters may be either primary facts or generalized propositions. The knowledge may have been acquired through the collection of records and reports; through the hearing of similar, related, or comparable cases; or through day to day contact with the field in which the agency operates. And the matters may be noticed in order to supplement the record, or to verify and weigh testimony appearing in it, or to draw appropriate conclusions." 6

Surely this is stretching the principle of judicial notice a long way. If an admimistrative agency can take official notice of any generalized proposition which it chooses to formulate from the experience of its own members and can permit such generalizations to outweigh the record of testimony-if this is to be the recognized procedure at administrative hearings one can only say that the nost fundamental of all safeguards against arbitrary action is being discarded:

All this is not to argue or imply that administrative tribunals

${ }^{6}$ Gemirhord, Federal Admintstrative Proceedings (1941) 96. 
should adopt and strictly follow the cautious procedure of the regular courts. To do that would take away most of their usefulness. Some of the rules which the regular courts followed with respect to the admissibility of evidence, for example, are outmoded. They would hamper, not help, the cause of fair administrative adjudication. But there are some fundamental principles of equitable dealing between man and man, as well as between a government and its citizens, which are the essence of civil liberty. No administrative tribunal can disregard them.save at the risk of gaining for itself an adverse reaction in the minds of those who still believe, with James Madison, that a government, in controlling the governed, must also learn to control itself.

Students of English legal history do not need to be told why Chancery and the Judicial Committee of the Privy Council survived while Star Chamber and High Commission disappeared in iguominy. All of them, in their origin, represented administrative interference with the normal jurisdiction of the regular courts. But the first two developed a judicialized attitude and an orderly procedure, which the last two did not. It may be set down as an axiom of political history that a free people will not permanently tolerate arbitrary adjudication no matter by what disarming name it may be called.

One of the much-debated questions of today relates to the grantmg of a right of appeal to the regular courts from the rulings of the administrative authorities. Vigorous objections have been raised against the granting of this privilege and some of them are valid. Interminable delays would certamly be involved, for at best the course of appeal in the regular courts is slow and their calendars are sometimes months in arrears. It would cripple the efficiency of administration if the right of judicial appeal were thrown open to anyone on any issue of law or fact. Rulings and orders could be, and would be assailed, not with the expectation of reversal, but merely as a way of gaining time. It is to be feared that some of the driving force behind the demand for broad appellate privileges is primarily inspired by a desire to slacken the speed at which governmental regulation can move. The right of appeal to the regular courts must be limited, and rather strictly limited, if for no other reason than to keep the routine administration of justice from becoming overwhelmed. If every ruling of the internal revenue bureau, for example, were subject to challenge in the federal district courts, these courts would have no time for much else. 
But the right of appeal can be accorded, as in this case, by setting up a special body for the purpose-the Board of Tax Appeals. It matters not how such appellate bodies may be constituted, provided they follow a procedure that gives everyone fair play (even as against the government) and are permitted to attain sufficient stability in the matter of personnel. May it not be that a solution of the larger problem can be found in the creation of such tribunals of administrative appeal? The crux of the problem is simply to give people their day in court whenever they feel that they have been wrongly treated by the administrative authorities while at the same time assuring to the latter a reasonable chance to do their work effectively. There need be no unreasonable delays if appeals are restricted to specialized tribunals which deal only with single categories of matters.

On the other hand it should be emphasized that no privilege of judicial review, whether by the regular or by special courts, will ever serve as a satisfactory substitute for intelligent and impartial administrative decisions in the first instance. What we most need, to this end, is better personnel and procedures lower down the line. Of these two, moreover, personnel is the more important, for although orderly procedure conduces to fair decisions it does not guarantee intelligent ones.

So if we must replace a government of laws by a government of men, as seems to a large extent inevitable, let us try to make it a government of men selected for their intelligence and fairmindedness, not as a reward for party service or as a means of "cementing alliances". In the long run the success or failure of administrative regulation is bound to depend upon whether this is done. With capable men striving to be fair in their rulings, the methods will take care of themselves. When procedure is found to be faulty, it can be improved; but when the personnel of a board or bureau lacks intelligence, this quality cannot be supplied by changing the rules. Nor can any one who is not endowed with fairness of mind be counted upon to reach impartial judgments, no matter what technique of adjudication he tries to follow.

Justice is the goal of all free government. It is the objective in all branches of government, administration included. And "good faith is the foundation of justice", as Cicero once said. A government of men should at least be a government by men of good faith. 


\section{California Law Review}

Published Quarterly throughout the Year by Students of the School of Jurisprudence of the University of California, Berkeley, California. Indexed in Index to Legal Periodicals, Public Affairs Information Service and Current Legal Thought.

Subscription Price, $\$ 3.50 \quad$ Current Single Copies, 90 Cents

\begin{tabular}{|c|c|c|}
\hline \multicolumn{3}{|c|}{ BOARD OF EDITORS } \\
\hline $\begin{array}{l}\text { HUGE W. FERRIER, } \\
\text { Associate Editor }\end{array}$ & $\begin{array}{l}\text { STEPHEN H. McReavy, } \\
\text { Associate Editor }\end{array}$ & $\begin{array}{c}\text { SIDNEY E. RoBERTs, } \\
\text { Associate Editor }\end{array}$ \\
\hline ALTERO D'AC & & L. RockWELI \\
\hline
\end{tabular}

Flora Dungan, Manager

\section{Correction to Last Issue}

In a Comment (Sept. 1942) 30 CALIF. L. REv. 667, 673, n. 32, it was stated that in the case of Mann v. Hearst (L. A. Co. Sup. Ct. No. 432,229, Sept. 1941) "A judgment for $\$ 1,771,859.21$ was rendered in favor of Consolidated against Hearst and certain holding companies controlled by him. None of the individual defendants except Hearst was held liable, although only part of them were wholly vindicated." This statement was based on the 222 page meinorandum opinion rendered by Judge Shinn in September, 1941.

We have since been informed that after reargument judgment was filed on November 10, 1941 granting recovery in favor of Hearst Consolidated Publications, Inc., against American Newspapers, Inc., and The Hearst Corporation but not against any other defendant. The findings signed on November 10, 1941 state that

(1) (I LXXXVI) All individual defendants acted ". . . in good faith, with honest intentions and motives and in the exercise of honest busmess judgment . ..." in all transactions.

(2) (I IXXXVIII) In each transaction found to be unfair to Consolidated "... it is also found that there were breaches of fiduciary duty upon the part of the corporations and certain of their officers, executives, and employees dealing with Consolidated ...."

(3) (II XC) "... although the use of dominating influence must be inferred as an inescapable conclusion from the facts in evidence.. the evidence is not sufficiently specific and direct to enable the court to identify the individual officers, executives, or employees exerting such influence . . .."

(4) (IIC) "In none of the matters involved in this litigation was defendant Hearst's participation in any transaction a breach of fiduciary duty on lis part individually."

It has also been brought to our attention that the total judgment rendered was for $\$ 5,022,258.89$, the figure of $\$ 1,771,859.21$ being a net figure resulting after the offsetting of certain debts owed by Consolidated to the defendant corporations held liable.

This case is noteworthy in that the plaintiffs and intervenors were awarded attorneys' fees in excess of $\$ 800,000$. An additional award of attorneys' fees $(\$ 60,000)$ was made to defendant John Francis Neylan. 